\title{
Life Cycle Analysis of Run-of River Small Hydro Power Plants in India
}

\author{
Varun $^{1, *}$ I. K. Bhat ${ }^{2}$ and Ravi Prakash ${ }^{3}$ \\ ${ }^{1}$ MED, NIT-Hamirpur (HP) - Indian; ${ }^{2}$ NIT-Hamirpur - India $;{ }^{3}$ MED, MNNIT Allahabad - India
}

\begin{abstract}
For 7-8\% growth rate that India is aspiringfor, its energy needs will increase correspondingly. The challenge is to provide desired quality power in a sustainable manner and at reasonable cost. Small hydropower has the potential of about $15000 \mathrm{MW}$ in India and considered to be a reliable source of electricity generation. Three run-of river small hydropower projects in India has been identified and their Life Cycle Analysis has been carried out by using the economic input-output (EIO) technique. The energy use, greenhouse gas (GHG) emissions and energy pay-back period (EPBT) were quantified for these small hydro power plants.
\end{abstract}

Keywords: Small hydro, economic input-output, energy pay-back period, greenhouse gas.

\section{INTRODUCTION}

Small Hydropower (SHP) is one of the earliest known renewable energy source. The technology was initially used in Himalayan villages in the form of water wheels to provide motive power to run devices like grinders. SHP technology was introduced in India shortly after the commissioning of the world's first hydro power plant at Appleton USA in
There is no international consensus on the definition of SHP. The general practice all over the world is to define SHP by power output. Different countries follow different norms keeping the upper limit ranging from 5 to $50 \mathrm{MW}$ [2]. In India, SHP schemes are classified by Central Electricity Authority (CEA) [3]. Table 1 shows the International definition of SHP whereas Table 2 shows the classification of SHP

Table 1. International Definition of Small Hydro

\begin{tabular}{|c|c|c|}
\hline S. No. & Country & Power (MW) \\
\hline \hline 1. & UK(NFFO) & $<5$ \\
\hline 2. & UNIDO & $<20$ \\
\hline 3. & Sweden & $<25$ \\
\hline 4. & Australia & $<25$ \\
\hline 5. & India & $<30$ \\
\hline 6. & China & $<30$ \\
\hline 7. & USA & $<50$ \\
\hline 8. & Brazil & $<50$ \\
\hline 10. & Philippines & New Zealand \\
\hline
\end{tabular}

1882. The $130 \mathrm{~kW}$ plant at Darjeeling in the year 1897 was the first SHP plant in the country. Few other power houses belonging to that period such as Shivasundaram in Mysore (2 MW, 1902), Galogi in Mussoorie (3 MW, 1907), Chaba (1.75 MW, 1914) and Jubbal (50 kW, 1930) near Shimla are still working properly [1].

*Address correspondence to this author at the MED, NIT-Hamirpur (HP) India; Tel: +91-1972-254742; Fax: +91-1972-223834;

E-mail: varun7go@gmail.com in India. In recent years small hydro electrical power has received great deal of attention from many points of view (i) as a sizeable and easily utilizable source of renewable energy and (ii) as a moderate investment method for providing electricity to under developed areas. Minimising the environmental impacts is one of the most significant technical and political challenges, energy sector is facing today. In India, rising electricity demands and rural development schemes has been continuously advocated for the development of SHP for the electricity generation as well as rural electrifica- 
Table 2. Classification of Small Hydropower in India

\begin{tabular}{|c|c|c|c|}
\hline S. No. & Type & Station Capacity (kW) & Unit Rating (kW) \\
\hline \hline 1. & Micro & Upto 100 & Upto 100 \\
\hline 2. & Mini & 101 to 2000 & 101 to 1000 \\
\hline 3. & Small & 2001 to 25000 & 1001 to 5000 \\
\hline
\end{tabular}

Table 3. Description of Small Hydropower Stations Selected for the Study

\begin{tabular}{|c|c|c|c|c|}
\hline S. No. & Name of Project & Year of Project & Capacity (kW) & Net Head (m) \\
\hline \hline 1. & Karmi micro hydro & 2005 & $2 \times 25$ & 55.0 \\
\hline 2. & Jakhna micro hydro & 2005 & $2 \times 50$ & 48.24 \\
\hline 3. & Rayat small hydro & 1996 & $3 \times 1000$ & 88.0 \\
\hline
\end{tabular}

tion. These projects have received worldwide concern in terms of their economic sustainability and issues of environment protection.

Life Cycle Analysis (LCA) is a tool for evaluating the environment impacts of a product or system through out its entire life span, usually from raw material extraction to final disposal. The LCA can be applied to assess the impact of electricity generation on the environment and will allow producers to make better decisions pertaining to environmental protection [4]. The two primary approaches for LCA are commonly used, one is based on Process Chain Analysis (PCA) and the second approach is based on Economic InputOutput (EIO) model.

Although only few references on hydropower are available yet, previous LCA studies and comparisons of various energy options have reported superior environmental performance for hydropower projects in terms of energy consumption and Global Warming Potential (GWP) [5]. These study reports give an overall life cycle results only which makes it difficult to distinguish exactly what is included and what assumptions are made in the study. Several studies have explicitly mentioned that emissions from the reservoir were considered [6,7].

\section{ABOUT THE PROJECTS: CASE STUDY}

Karmi-III micro hydro power project is located $36 \mathrm{~km}$ from Bageshwar town in district of Bageshwar Uttarakhand (India) by road upto Godiyadhar village and followed $8 \mathrm{~km}$ by foot track. This project envisages diversion of water from KARM GAD which is tributary of river Saryu through a semi permanent weir by $93 \mathrm{~m}$ long, $0.275 \mathrm{~m}$ diameter steel pipe and utilising $55.0 \mathrm{~m}$ of net head. Two hydraulic turbines of $25 \mathrm{~kW}$ each with synchronous generators are installed and power is transmitted through $11 \mathrm{kV}$ lines to 5 villages (Dobar, Topania, Munar, Thalidar and Khalidar). The area falls in the humid temperate zone of higher Himalaya.The maximum temperature is in the range of $30^{\circ} \mathrm{C}$ to $0^{\circ} \mathrm{C}$ during summer and winter respectively. Karmi micro hydro plant is located in zone (V) of the seismic zone map of India, accordingly the basic seismic coefficient for the site is to be selected [8].
Jakhna Micro hydro power project is at the remote hilly area of Bhilangana block of Tehri Garwhal district of Uttarakhand (India). This area receives all its supplies from Gansali, which is about $44 \mathrm{~km}$ from the site. The temperature in the project area is generally between $3{ }^{\circ} \mathrm{C}$ to $30^{\circ} \mathrm{C}$ and humidity between 30 to $85 \%$. The gross head $(\mathrm{H})$ of the plant is $52.74 \mathrm{~m}$ while net head is $48.24 \mathrm{~m}$. The design discharge is $0.28 \mathrm{~m}^{3} / \mathrm{s}$ and the installed capacity of the plant is $100 \mathrm{~kW}$ $(2 \times 50)$ [9]. This scheme electrifies villages of Jakhna, Bhaildgaon and Toli with a total population of nearly 260 families. The population is generally poor and the literacy rate is nearly $50-55 \%$. Village Jakhna, Toli and Bhaildgaon are situated on the banks of river Balganga in Thati valley of Bhilangana block. An attempt to draw power from the Grid will be costlier and may involve deforestation at large scale. It was observed that irrigation canal exists in the area which passes just above the village Jakhna. Local enquiry has revealed that the water of this canal is used for 15-20 days in a year otherwise it lies unutilized hence this existing canal is used as power channel.

Rayat small hydro power project is located at a distance of about $12 \mathrm{~km}$ from Kempty falls in the District of Tehri Garwhal in Uttarakhand near village Nautha. The project utilizes perennial water of Aglar river for power generation without affecting the environment. The maximum and minimum temeperature are in the range of $35^{\circ} \mathrm{C}$ to $5^{\circ} \mathrm{C}$ during the summer and winter respectively. This project is located in earthquake zone (IV) of the seismic zone map of India, and the basic seismic coefficient for the site is selected as 0.05. The available net head is $88.0 \mathrm{~m}$ and the installed capacity of the plant is $3000 \mathrm{~kW}(3 \times 1000)$ [10]. Table 3 shows the description of the hydropower stations selected for the study.

\section{METHODOLOGY}

LCA is a tool for evaluating the environmental impacts of a product or project through its entire life span, usually from raw material extraction to its final disposal (cradle to grave). Of the two primary approaches for LCA, EIO based LCA approach has been adopted in the present study. The EIO-LCA approach consists of a matrix of economic data (representing the inputs from all sectors of the economy into all other sectors and the distribution of each sector's output throughout the economy) and a matrix of sector level envi- 
Table 4. Inventory of Energy Use and GHG Emissions in Civil Works

\begin{tabular}{|c|c|c|c|c|c|c|c|c|c|c|c|c|c|}
\hline \multirow{2}{*}{$\begin{array}{c}\text { S. } \\
\text { No. }\end{array}$} & \multirow{2}{*}{ Component } & \multicolumn{3}{|c|}{$\begin{array}{c}\text { Cost in Rs 2004-05 } \\
\left(10^{6}\right)\end{array}$} & \multicolumn{3}{|c|}{ Cost in US \$ $(1997)\left(10^{6}\right)$} & \multicolumn{3}{|c|}{ Energy Use (TJ) } & \multicolumn{3}{|c|}{ GHG Emission $\left(\mathrm{MgCO}_{2 \mathrm{eq}}\right)$} \\
\hline & & 1 & 2 & 3 & 1 & 2 & 3 & 1 & 2 & 3 & 1 & 2 & 3 \\
\hline 1. & Construction & 2.891 & 2.126 & 65.845 & 0.266995 & 0.196344 & 6.081043 & 2.087902 & 1.535413 & 47.55375 & 160.7311 & 118.1993 & 3660.788 \\
\hline 2. & Erection & 0.313 & 0.588 & 10.59 & 0.028907 & 0.054304 & 0.978028 & 0.226051 & 0.424658 & 7.648178 & 17.40188 & 32.69106 & 588.7728 \\
\hline
\end{tabular}

Table 5. Inventory of Energy Use and GHG Emissions in E\&M Equipment

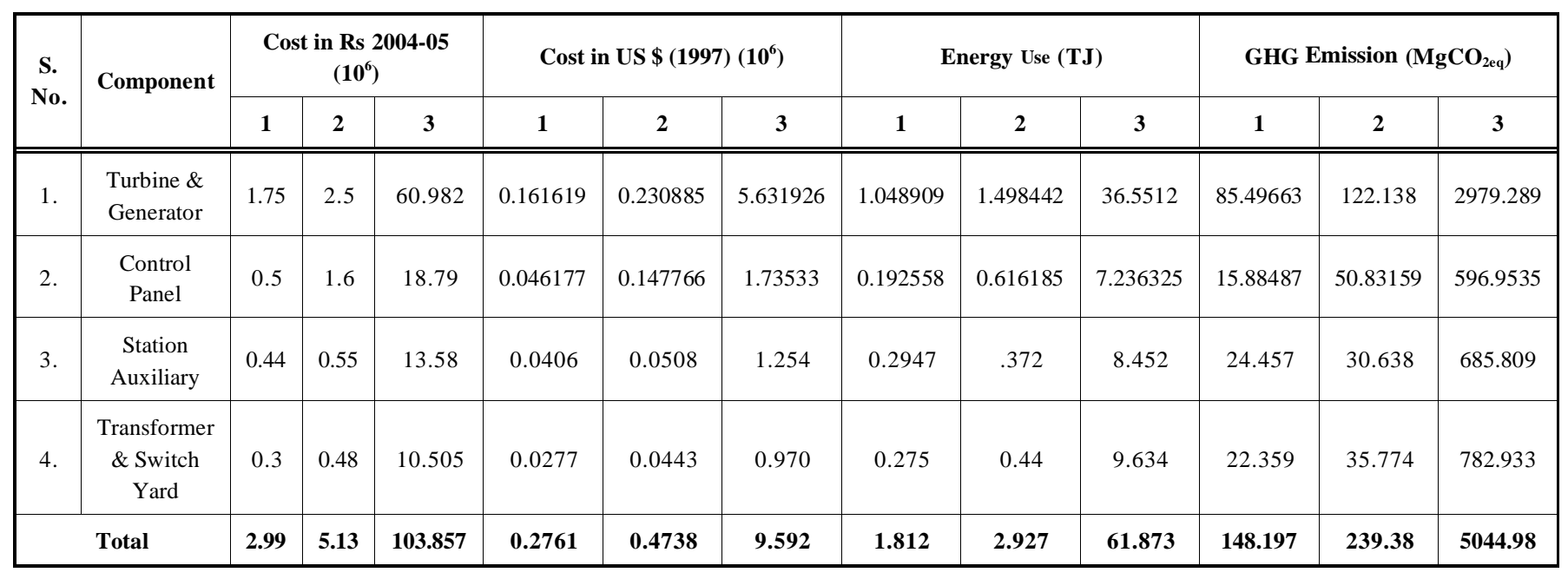

ronmental coefficients [11]. EIO based software of the U.S. economy is developed by the Green Design Institute at Carnegie Mellon University. In this study EIO-LCA model is used to account for the energy input and GHG emissions associated with the manufacturing of major materials and equipment used in these projects. Since no EIO-LCA model has been developed for India, the Carnegie Mellon EIO-LCA software (US Deptt of Commerce 1997 Industry Benchmark) is used in the present study [12]. The cost estimates of these projects pertain to different years. These costs have been inflated using inflation table of India to bring all the costs at par at the level of year 2004-05 in Indian Rs. Further the costs are converted into equivalent U.S. dollars by using the purchase power parity (PPP) in that year (2004). Further U.S. dollar has been adjusted for the year 1997 by using the U.S. Consumer price index (CPI) (see appendix 1) [13-14].

In this study, a functional unit is taken as $1 \mathrm{kWh}$ of net electricity produced by small hydro power. GHG emissions are normalised to an equivalent of $\mathrm{CO}_{2}$ (gm) (see appendix 2) emissions per $\mathrm{kWh}$ of net electricity production based on IPCC 100 year Global Warming Potentials (GWP) [15]. The material input and monetary costs are extracted from detailed project report (DPRs) of the projects and visiting the site. Fig (1) shows a schematic diagram of run-of river small hydropower layout. Life cycle of a small hydro project is divided into four stages: (i) Civil works (ii) Electro-mechanical equipment (E\&M) (iii) Operation and Maintenance (O\&M) (iv) and Decommissioning.

$$
E P B T=\frac{\text { Energy input in all stages }(J)}{\text { Output energy per year }(J / y r)}
$$

\section{LIFE CYCLE INVENTORY ANALYSIS}

\subsection{Civil Works}

The inventory of civil works estimated in these projects are summarized in Table 4, which accounts for major construction material in the components such as diversion, channel, forebay tank, penstock and transportation, erection etc. The total energy use and Greenhouse gas (GHG) emissions for each item is obtained from the EIO-LCA software. The inputs associated with the extraction of raw materials through the manufacturing of the material and equipment has been included in the EIO-LCA software.

\subsection{Electro-Mechanical Equipment}

The inventory of E\&M equipment used in these projects are summarized in Table 5, which accounts for the major electro-mechanical equipments, control structures, transformer and switchyard and station auxiliaries (valves, battery, PVC cables etc). The total energy use and GHG emissions for each item is obtained from the EIO-LCA software. The inputs associated with all processes from extraction of raw materials to manufacturing of the materials and equipments are included in the EIO-LCA software. 
Table 6. Inventory of Energy Use and GHG Emissions in Annual O\&M

\begin{tabular}{|c|c|c|c|c|c|c|c|c|c|c|c|c|c|}
\hline $\begin{array}{l}\text { S. } \\
\text { No. }\end{array}$ & Component & \multicolumn{3}{|c|}{ Cost in Rs 2004-05 $\left(10^{6}\right)$} & \multicolumn{3}{|c|}{ Cost in US \$ (1997) $\left(10^{6}\right)$} & \multicolumn{3}{|c|}{ Energy Use (TJ) } & \multicolumn{3}{|c|}{ GHG Emission $\left(\mathrm{MgCO}_{2 \mathrm{eq}}\right)$} \\
\hline 1. & Civil works & 0.10866 & 0.10209 & 2.44218 & 0.010035 & 0.009429 & 0.22554 & 0.08679 & 0.08745 & 1.86264 & 6.90744 & 7.1037 & 146.0799 \\
\hline 2. & E\&M works & 0.0897 & 0.1539 & 3.11571 & 0.008283 & 0.014214 & 0.28776 & 0.05436 & 0.08781 & 1.85619 & 4.44591 & 7.1814 & 151.3494 \\
\hline 3. & Others & 0.02 & 0.15 & 1.71 & 0.001847 & 0.013844 & 0.157925 & 0.011193 & 0.083896 & 0.899527 & 0.957027 & 6.742175 & 76.90956 \\
\hline
\end{tabular}

Table 7. Total Life Cycle Inventory of Energy Use and GHG Emissions of Projects

\begin{tabular}{|c|c|c|c|c|c|c|c|c|c|c|c|c|c|}
\hline $\begin{array}{c}\text { S. } \\
\text { No. }\end{array}$ & Component & \multicolumn{3}{|c|}{ Cost in Rs 2004-05 $\left(10^{6}\right)$} & \multicolumn{3}{|c|}{ Cost in US \$ (1997) $\left(10^{6}\right)$} & \multicolumn{3}{|c|}{ Energy Use (TJ) } & \multicolumn{3}{|c|}{ GHG Emission $\left(\mathrm{MgCO}_{2 \mathrm{eq}}\right)$} \\
\hline 1. & Civil works & 3.622 & 3.403 & 81.406 & 0.3345 & 0.3143 & 7.518 & 2.893 & 2.915 & 62.088 & 230.248 & 236.79 & 4869.33 \\
\hline 2. & E\&M works & 2.99 & 5.13 & 103.857 & 0.2761 & .4738 & 9.592 & 1.812 & 2.927 & 61.873 & 148.197 & 239.38 & 5044.98 \\
\hline 3. & $\mathrm{O} \& \mathrm{M}^{*}$ & 6.5508 & 12.1797 & 218.0367 & 0.60495 & 1.12461 & 20.13675 & 4.57029 & 7.77468 & 138.5507 & 369.3114 & 630.8184 & 11230.17 \\
\hline
\end{tabular}

*for 30 years life

Table 8. Energy Pay-Back Period and GHG Emissions of Small Hydro Power Houses

\begin{tabular}{|c|c|c|c|c|c|}
\hline S. No. & Name of Power House & Capacity $(\mathbf{k W})$ & $\begin{array}{c}\text { Energy Generated } \\
(\mathbf{k W h} / \mathbf{y e a r})\end{array}$ & EPBT (years) & $\begin{array}{c}\text { GHG Emissions } \\
\left(\mathbf{g C O} \mathbf{}_{\mathbf{2 e q}} / \mathbf{k W h} \mathbf{e}\right.\end{array}$ \\
\hline \hline 1. & Karmi-III & 50 & 332880 & 2.71 & 74.88 \\
\hline 2. & Jakhna & 100 & 665760 & 1.99 & 55.42 \\
\hline 3. & Rayat & 3000 & 19972800 & 1.28 & 35.29 \\
\hline
\end{tabular}

\subsection{Operation and Maintenance}

The general estimates for the energy use and GHG emissions are based on the annual maintenance cost and use of machine tools etc. Based on the project scale, the annual maintenance cost is taken as $3 \%$ of the total civil works and $3 \%$ of electro-mechanical equipment. Annual plant electricity usage is estimated as $5 \%$ of the annual electricity output. The amount of flooded biomass per unit of reservoir area can vary from $500 \mathrm{Mg} / \mathrm{ha}$ for tropical forest to $100 \mathrm{Mg} / \mathrm{ha}$ for a boreal climate [16], whereas the carbon content of different ecosystems varies from $18.8 \mathrm{~kg}$ of $\mathrm{CO}_{2 \mathrm{eq}} / \mathrm{m}^{2}$ for tropical forests to $0.3 \mathrm{~kg}$ of $\mathrm{CO}_{2 \mathrm{eq}} / \mathrm{m}^{2}$ for desert shrub. In the SHP scheme studied, there is no storage of water, henceno change in terrestrial ecosystem is considered. Table $\mathbf{6}$ shows annual energy use and annual GHG emissions in the operation and maintenance stage.

\subsection{Decommissioning}

The major components used in the power house are expected to last for 20-35 years. The energy consumption and GHG emissions for replacement and maintenance have been averaged and included in the operation and maintenance stage. Ideally decommissioning stage is also very important in accounting the total inventory of energy use and GHG emissions. However, the practice of demolition of small hydro power structures and components are very uncommon for the reason of renovation, modernization and uprating of the existing power house. As a power house completes its life, it goes for renovation, modernization and uprating. So there is no need to demolish the existing power house, but only to modify as per the condition of project site at that particular time. Table 7 summarizes the life cycle inventory of these projects.

\section{RESULTS AND DISCUSSIONS}

\subsection{Energy Pay Back Period}

Project costs are not directly proportional to the energy use or environmental loads. For these projects, civil works share is $31.19,21.41$ and $23.65 \%$. E\&M equipment share is $19.54,21.50$ and $23.57 \%$ and O\&M work share is 49.27, 57.09 and $52.78 \%$ respectively for the Karmi-III, Jakhna and Rayat power plant respectively. The annual net energy generation for the three power plants at $80 \%$ load factor after deducting 5\% energy as auxiliary consumption are 3.3288 , 6.6576 and 199.728 lac units for Karmi-III, Jakhna and Rayat power plant respectively. The average life of the power plant is assumed to be 30 years. The EPBT for these power plant have been worked out as 2.71, 1.99 and 1.28 years respectively as shown in Table $\mathbf{8}$. 


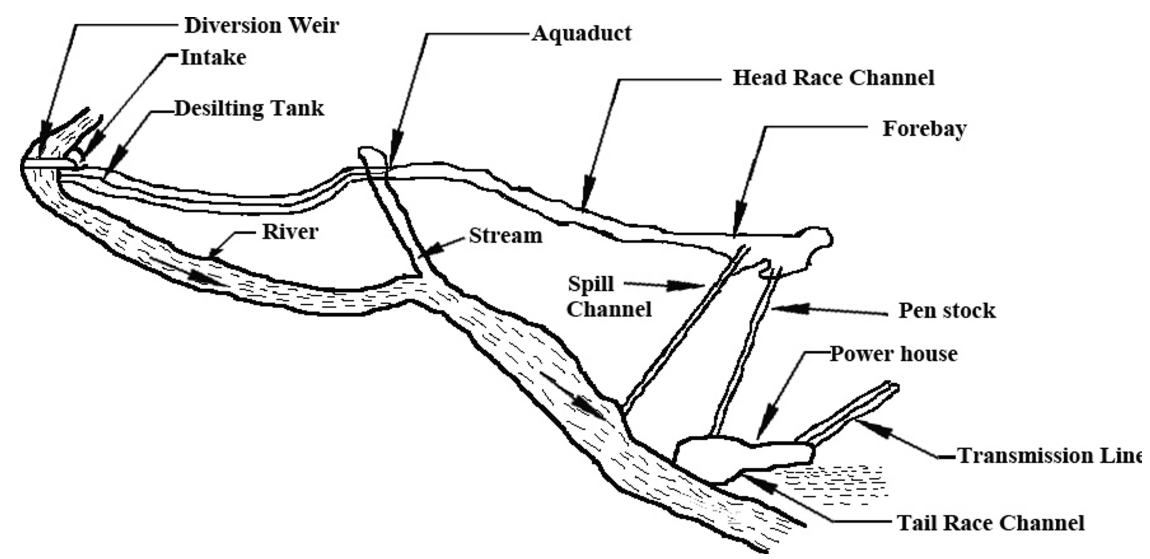

Fig. (1). Layout of a Run-of-River small hydro power scheme.

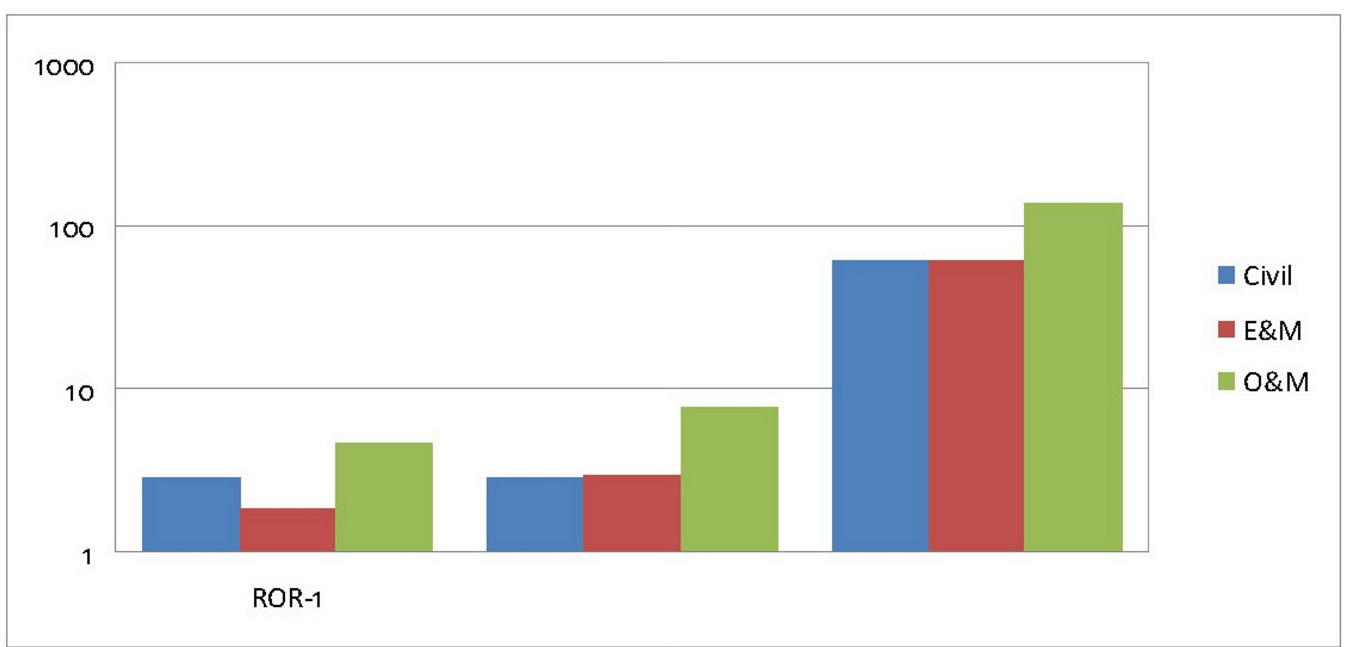

Fig. (2). Variation of GHG emissions for different power houses.

\subsection{GHG Emissions}

The contribution of GHG emissions from each life cycle stages for these three power plant has been evaluated. The GHG emissions shared by civil works are 30.79, 21.39 and $23.03 \%$, E\&M equipment shares are 19.82, 21.62 and $23.86 \%$ and O\&M shares are 49.39, 56.99 and $53.11 \%$ respectively for the Karmi-III, Jakhna and Rayat power plant respectively. The total GHG emissions are 747.7564, 1106.988 and $21144.48 \mathrm{MgCO}_{2 \mathrm{eq}}$ respectively. The GHG emission for power houses are estimated 74.88, 55.42 and $35.29 \mathrm{gCO}_{2 \mathrm{eq}} / \mathrm{kWh}_{\mathrm{e}}$ for the Karmi-III, Jakhna and Rayat power plant respectively as shown in Table 8. Fig. (2) shows the variation of GHG emissions for civil, electromechanical and O\&M works share for three different run-of river SHP power plants.

\section{CONCLUSIONS}

In this study, the LCA of three run-of river small hydropower plants has been carried out. The EPBT of these power houses varies from 1.28 to 2.71 years and GHG emissions vary from 35.29 to $74.88 \mathrm{gCO}_{2 \mathrm{eq}} / \mathrm{kWh}_{\mathrm{e}}$. The variation in the EPBT and GHG emissions shows that as the capacity of the power house increases EPBT and GHG emissions decreases. The EPBT and GHG emissions from small hydro power generation system are less as compared to the conventional type of electricity generation systems.

\section{SUPPLEMENTRY MATERIAL}

Supplementary material can be viewed at www.bentham.org/open/torej

\section{REFERENCES}

[1] Baidya, G. In Development of Small Hydro, Proceedings of the International Himalayan Small Hydropower Summit (HSHS), Dehradun, India, Oct 12-13, 2006; Sharma, J. D.; Sinvhal, H.; Saraf, A. K.; Saini, R.P.; Singal, S.K.; Ahmad, Z., Eds: Alternate Hydro Energy Center: Roorkee, India, 2006; pp. 30-38.

[2] Naidu, B. S. K. Small Hydro; $1^{\text {st }}$ ed.; NPTI Publication; Faridabad, India, 2005.

[3] Varun; Bhat, I. K.; Prakash, R. In Small Hydro Power- A Sustainable Source of Renewable energy, Proceedings of the National Conference on Energy and Environment, Jaipur, India, Nov 25-26, 2006; Saraogi, L.K.; Gaur, Y.N.; Bhardwaj, R.K.; Naresh, D.N., Eds.; Jaipur Engineering College: Jaipur, India, 2006; pp. 229-236.

[4] Goralczyk, M. Life cycle assessment in the renewable energy sector. Appl. Energy, 2003, 75, 205-211.

[5] Zhang, Q.; Karney, B.; Maclean H.L.; Feng J. Life-Cycle inventory of energy use and greenhouse gas emissions for two hydropower projects in china. JIS ASCE, 2007, 13 (4), 271-279.

[6] Rosa, L.P.; Schaeffer, R. Global warming potentials- the case of emissions from dams. Energy Policy, 1995, 23 (2), 149-158.

[7] Gagnon, L.; Vate, J.F.V. Greenhouse gas emissions from hydropower. Energy Policy, 1997, 25 (1), 7-13.

[8] Detailed Project Report. Karmi-III Micro Hydropower Project, AHEC, Indian Institute of Technology Roorkee (India), 2005.

[9] Detailed Project Report. Jakhna Micro Hydropower Project, AHEC, Indian Institute of Technology Roorkee (India), 2005. 
[10] Detailed Project Report. Rayat Mini Hydel Project, A. Power Himalayas Limited, Shamsherpur Paonta Sahib (India) January 1996

[11] Bullard, C.W.; Penner, P.S.; Pilati, D.A. Net Energy Analysis Handbook for combining process and Input-Output analysis. Resour. Energy, 1978, 1, 267-313.

[12] Carnegie Mellon University Green Design Institute (CMU-Green Design Institute). Economic input-output life cycle assessment (EIO-LCA) model. http://www.eiolca.net/(accessed June 10, 2008).

[13] http://inflation.com (accessed July 15, 2008).
[14] The World Bank, Relative prices and exchange rates, world development indicators, 2004

[15] Henrikke, Baumann; Anne Marie Tillman. A Hitch-Hiker guide to $L C A$, Studentlitteratur, Sweden, 2004.

[16] Gagnon, L.; Belanger, C.; Uchiyama, Y. Life cycle assessment of electricity generation options: The status of research in year 2001 . Energy Policy, 2002, 30, 1267-78.

(C) Varun et al.; Licensee Bentham Open.

This is an open access article licensed under the terms of the Creative Commons Attribution Non-Commercial License (http://creativecommons.org/licenses/by-nc/3.0/) which permits unrestricted, non-commercial use, distribution and reproduction in any medium, provided the work is properly cited. 